Weldy Agiwinata : Konvensi Ketatanegaran

\title{
KONVENSI KETATANEGARAAN SEBAGAI BATU UJI DALAM PENGUJIAN UNDANG-UNDANG DI MAHKAMAH KONSTITUSI
}

\author{
Weldy Agiwinata \\ weldy.agiwinata@gmail.com \\ Universitas Palangkaraya
}

\begin{abstract}
This research attempts to analyze in normative manner the use of constitutional convention as source of laws and cause of action for Constitutional Court (Mahkamah Konstitusi) in constitutional review and to explain further the meaning of constitutional convention as unwritten law. This research indicates that: constitutional convention cannot be included into legal regulation hierarchy. Refers to the meaning and concept of convention as unwritten law cannot be included because it will violate the essence of constitutional convention as unwritten law; The role of constitutional law is to cover the weaknesses of constitutional regulations can be used as a companion to written constitution serves as reference for The Constitutional Court, so that the existing and respected constitutional values and practices need to be considered. It also functions to preserve values which are considered as sacred or it is considered impossible to amend the constitution quickly because of constitutional issues.
\end{abstract}

Keywords: constitutional court, constitutional convention, unwritten law

\begin{abstract}
Abstrak
Penelitian ini bertujuan untuk menganalisis secara normatif, penggunaan konvensi ketatanegaraan sebagai sumber hukum dan dasar hukum oleh Mahkamah Konstitusi dalam pengujian undang-undang dan menguraikan secara mendalam makna konvensi ketatanegaraan sebagai hukum yang tidak tertulis. Hasil penelitian menunjukan konvensi ketatanegaraan memuat nilainilai dari konstitusi namun tidak dapat dimasukan kedalam hierarki peraturan perundang-undangan. Hal ini agar esensi dari konsep konvensi ketatanegaraan yang merupakan hukum tidak tertulis tidak hilang dengan dituliskannya ke dalam bentuk tertulis. Keberadaan konvensi ketatanegaraan menutupi kelemahan peraturan perundang-undangan untuk mengatur seluruh kehidupan bernegara yang dapat dijadikan sebagai pendamping dari konstitusi tertulis dan dijadikan sebagai batu uji oleh Mahkamah Konstitusi, sehingga nilai-nilai ataupun kebiasaan ketatanegaraan yang selama ini telah ada dan dihormati tetap diperhatikan, juga untuk menjaga nilai yang dianggap sakral atau tidak mungkin untuk merubah UUD secara cepat karena suatu masalah ketatanegaraan
\end{abstract}

Kata kunci: hak keperdataan, anak luar kawin, keadilan 


\section{Pendahuluan}

Hukum berasal dari moral atau kebaikan (goodness), sehingga menurut Peter Mahmud Marzuki cinta kasih dan sikap kebersamaan itulah merupakan landasan kehidupan masyarakat. Rasa cinta kasih dan sikap kebersamaaan itulah disebut moral. ${ }^{1}$ Moral merupakan sesuatu yang abstrak atau bias. Tidak adanya aturan hukum tidak mengapa jika mengacu dari pengertian moral tersebut. Namun, hal itu tidak dapatdilakukan didalam kehidupan masyarakat modern saat ini karena pengaruh dari dinamika hukum seperti yang dijelaskan oleh Llewellyn dan Hobel karena kebiasaan yang merujuk kepada praktek yang terbentuk.

Dua faktor utama dalam dinamika hukum, yaitu perkembangan yang tidak disadari dan tuntutan individual secara sadar itulah hukum. ${ }^{2}$ Kesadaran akan perlu adanya aturan itulah yang disebut sebagai opinion neccesitatis. ${ }^{3}$ Sebagai contoh praktik-praktik yang terjadi yang kemudian dilakukan terus-menerus sehingga tidak nampak sebagai kesalahan adalah bahwa setiap keputusan yang berkaitan dengan keuangan negara baik kebijakan penetepan tarif pajak atau retribusi lazimnya merupakan tugas Menteri Keuangan namun pada praktiknya justru Direktur Jendral Pajak yang menetapkan akan hal tarif pajak.

Sebagai suatu ilmu, ilmu hukum masuk kedalam bilangan ilmu yang bersifat preskriptif, artinya ilmu yang membawa atau sarat nilai. Ilmu yang bersifat menganjurkan bukan hanya mengemukakan apa adanya. Oleh karena itu, ilmu hukum bukan termasuk ke dalam bilangan ilmu empiris ${ }^{4}$ karena ilmu hukum mempelajari tentang perbuatan atau tindakan (act) yang berkaitan dengan norma atau prinsip hukum.

Hukum yang berlaku dalam suatu sistem hukum tertentu (the prevailing law) bukan hanya hukum positif atau yang dibuat oleh penguasa saja, melainkan juga hukum kebiasaan dan praktik-praktik yang sudah diterima sebagai hukum di masyarakat. Adapun sumber hukum yang mempunyai arti yang bermacam-macam, tergantung dari sudut mana kita melihatnya. Menurut Utrecht yang sebagaimana dikutip oleh Mochtar Kusumaadmadja dan Arief Sidharta, mengenai sumber hukum dapat dibagi kedalam arti formal dan materiil. ${ }^{5}$

Sumber hukum dalam arti formal adalah sumber hukum yang dikenal karena bentuknya. Karena bentuknya itu, hukum berlaku umum, diketahui, dan ditaati. Selanjutnya untuk menetapkan suatu kaidah hukum itu, diperlukan suatu badan yang berwenang dimana kewenangan badan tersebut diperoleh dari kewenangan badan yang lebih tinggi. Sumber hukum dalam arti formal terdiri dari peraturan perundang-undangan, kebiasaan-kebiasaan ketatanegaraan, yurisprudensi, traktat, dan doktrin. ${ }^{6}$ Sumber hukum meteriil adalah faktorfaktor masyarakat yang mempengaruhi pembentukan hukum seperti pengaruh terhadap

\footnotetext{
1 Peter Mahmud Marzuki, Pengantar Ilmu Hukum, Prenada Media Group ,Jakarta:2008, hal.43

Ibid., hal 53

Ibid.

Ibid, hal. 9

5 Mochtar Kusumaatmadja dan B. Arief Sidharta, Pengantar Ilmu Hukum Suatu Pengenalan Pertama Ruang Lingkup Berlakunya Ilmu Hukum, Bandung: Alumni, 2000, hal.54

${ }^{6}$ Bagir Manan, Konvensi Ketatanegaraan, Bandung, Armico: 1987, hal 14
} 
pembuat undang-undang, pengaruh terhadap keputusan hakim, dan sebagainya, faktor-faktor yang ikut mempengaruhi materi dari aturan-aturan hukum, atau tempat dari mana materi hukum itu diambil. ${ }^{7}$ Sama halnya dengan konvensi ketatanegaraan yang merupakan salah satu hukum yang tidak tertulis.

Istilah konvensi berasal dari bahasa Inggris convention. Secara akademis seringkali istilah tersebut digabungkan dengan constitutional atau dikenal dengan constitutional convention. ${ }^{8}$ Konvensi atau hukum kebiasaan ketatanegaraan adalah hukum yang tumbuh dalam praktik penyelenggaraan negara untuk melengkapi, menyempurnakan, dan menghidupkan kaidahkaidah hukum perundang-undangan atau hukum adat ketatanegaraan. ${ }^{9}$

Konvensi ketatanegaraan walaupun bukan sebagai aturan hukum yang tertulis, keberadaannya diakui dan dijalankan dalam sistem ketatanegaraan di Indonesia. Bahkan ketika hukum yang tertulis tidak mampu menyelesaikan permasalahan, maka konsep hukum yang digunakanadalah asas hukum yang berisikan moral dan norma-norma kebiasaan untuk dapat memberikan rujukan untuk menyelesaikan masalah ketatanegaraan.

Ketentuan Pasal 18 ayat (1) dan Pasal 22 ayat (1) huruf d UU Nomor 16 Tahun 2004 sebagai contoh dianggap menimbulkan ketidakpastian hukum karena tidak memberikan kejelasan batas masa jabatan Jaksa Agung Oleh karenanya Yusril Ihza Mahendra mengajukan pengujian atas Undang-Undang tersebut untuk diuji terhadap UUD NRI 1945. Dari pasal tersebut dapat ditafsirkan jika tidak meninggal dunia, tidak mengajukan permintaan untuk berhenti, tidak sakit jasmani atau rohani terus menerus, tetap memenuhi syarat sebagai Jaksa Agung, maka seorang Jaksa Agung tidak dapat diberhentikan oleh Presiden. Ditafsirkan demikian karena Undangundang tersebut tidak mengatur kapan akhir masa jabatan Jaksa Agung. Keadaan ini berpotensi menjadikan seorang Jaksa Agung akan memangku jabatan seumur hidup. Jabatan Jaksa Agung adalah political appointee. Jaksa Agung bisa berasal dari jaksa karier dan bisa dari luar institusi kejakasaan; tetapi yang jelas itu adalah jabatan politik. maka Jaksa Agung dapat diberhentikan oleh Presiden kapan saja, kalau dianggap tidak mampu menjalankan tugas. ${ }^{10}$

Pada masa pemerintahan Presiden Soeharto, Presiden BJ Habibie, Presiden Abdurrahman Wahid dan Presiden Megawati, Jaksa Agung selalu menjadi anggota kabinet dengan kedudukan setingkat menteri negara. Masa jabatan Jaksa Agung berakhir dengan berakhirnya masa jabatan Presiden dan berakhirnya masa bakti kabinet yang dibentuknya. Keadaan yang telah berlangsung terus-menerus semenjak tahun 1961 hingga dibahasnya RUU Kejaksaan tahun 2004, telah dapat dianggap sebagai konvensi ketatanegaraan yang dalam praktek diterima dan diakui. Kebiasaan ketatanegaraan pernah juga dipakai sebagai dasar dalam melakukan pengujian dalam masalah pengangkatan Wakil Menteri yang telah diuji dalam putusan 79/PUU-IX/2011. Polemik pengujian dilakukan menyusul 20 nama wakil menteri baru diangkat oleh presiden

\footnotetext{
Ni’Matul Huda, Hukum Tata Negara Indonesia, PT Raja Grafindo Persada, Jakarta: 2012, hal.31

8 H. Dahlan Thaib,dkk, Teori dan Hukum Konstitusi, PT Raja Grafindo Persada, Jakarta: 2006, hal. 129

9 Ni'Matul Huda, Hukum Tata Negara Indonesia...loc.,cit..hal. 34

10 Pendapat dari Dr. Andi Muhhamad, S.H.,M.H, yang dibenarkan oleh hakim Mahkamah Konstitusi didalam putusannya.
} 
Susilo Bambang Yudhoyono dalam kabinet Indonesia Bersatu Jilid II. Berkaitan dengan hal tersebut Adi Warman dan H.TB.Imamnudin dari Gerakan Nasional Pemberantasan Tindak Pidana Korupsi (GN-PK) mendalilkan hal ini bertentangan dengan konstitusi bahwa pasal 10 Undang-undang Nomor 39 tahun 2008 tentang Kementerian Negara bertentangan dengan Pasal 17 UUD NRI Tahun 1945 karena dalam Pasal 17 UUD NRI 1945 tidak ada menyebutkan jabatan Wakil Menteri.

MK berpendapat bahwa karena ketentuan Pasal 17 UUD 1945 hanya menyebutkan menteri-menteri negara, tanpa menyebutkan wakil menteri, maka menurut Mahkamah kalau menteri dapat diangkat oleh Presiden, logikanya bahwa Presiden pun tentu tidak dapat mengangkat wakil menteri. Tidak adanya perintah maupun larangan di dalam UUD 1945 memberi arti berlakunya asas umum di dalam hukum bahwa "sesuatu yang tidak diperintahkan dan tidak dilarang itu boleh dilakukan" dan dimasukkan di dalam Undang-Undang sepanjang tidak berpotensi melanggar hak-hak konstitusional atau ketentuan-ketentuan lain di dalam UUD 1945. Adanya jabatan wakil menteri bukanlah pertama kalinya selaku saksi ahliYusril Ihza Mahendra tidak menepis adanya konvensi ketatanegaraan karena yakni, adanya tiga wakil menteri dalam anggota kabinet pertama Presiden Soekarno. Selain itu, pada masa pemerintahan orde baru, presiden Soeharto juga pernah mengangkat menteri muda. ${ }^{11} \mathrm{Hal}$ tersebut yang memperkuat pendapat penulis mengenai konvensi ketatanegaraan yang secara implisit disampaikan oleh Mahkamah Konstitusi dalam putusannya tersebut.

Konvensi ketatanegaraan juga digunakan sebagai pertimbangan hukum dalam pengujian undang-undang sebagaimana putusan MK perkara Nomor 51-52-59/PUU-VI/2008 tanggal 18 Pebruari 2009, dalam uji materi Pasal 3 Ayat (5) UU No. 42 Tahun 2008 tentang Pemilihan Umum Presiden dan Wakil Presiden. MK dalam pertimbangan hukumnya berpendapat bahwa terhadap Pasal 3 ayat (5) UU No.42 Tahun 2008 tentang Pemilihan Umum Presiden dan Wakil Presiden, Mahkamah Konstitusi berpendapat bahwa hal tersebut merupakan cara atau persoalan prosedural yang dalam pelaksanaannya acapkali menitikberatkan pada tata urut yang tidak logis atas dasar pengalaman praktik ketatanegaraan yang biasa dilakukan.

Pemilu Presiden dan Wakil Presiden dilaksanakan setelah pelaksanaan Pemilu DPR, DPRD dan DPD. Pengalaman yang telah berjalan ialah Pemilu Presiden dilaksanakan setelah Pemilu DPR, DPD, dan DPRD, karena Presiden dan/atau Wakil Presiden dilantik oleh Majelis Permusyawaratan Rakyat, sehingga Pemilu DPR dan DPD didahulukan untuk dapat dibentuk MPR. Lembaga inilah yang kemudian melantik Presiden dan Wakil Presiden, oleh karenanya harus dibentuk lebih dahulu. Dalam hal ini sesungguhnya telah terjadi apa yang disebut desuetudo atau kebiasaan telah menggantikan ketentuan hukum, yaitu suatu hal yang seringkali terjadi baik praktik di Indonesia maupun di negara lain karena kebiasaan demikian telah diterima dan dilaksanakan, maka dianggap tidak bertentangan dengan hukum. Dengan demikian Pasal 3 ayat (5) UU No.42 tahun 2008 tidaklah bertentangan dengan konstitusi.

\footnotetext{
11 Majalah Konstitusi, Edisi Maret 2012, hal.5
} 


\section{Konsep Konvensi Ketatanegaraan}

Istilah konvensi ketatanegaraan berasal dari bahasa Inggris. Namun istilah ini tidak dapat disamakan dengan istilah konvensi konstitusi yang dikenal di Amerika, konvensi konstitusi yang dikenal dinegara tersebut mempunyai pengertian yang merupakan kebiasaan-kebiasaan dalam pembentukan konstitusi itu sendiri atau dengan kata lain pengkodifikasian dari konvensi itu sendiri. ${ }^{12}$ Convention atau lebih dikenal dengan istilah constitutional convention, yang diteliti lebih dalam oleh Dicey seorang sarjana Inggris sebagaimana yang dikutip oleh Dahlan Thaib yang mula-mula mempergunakan istilah konvensi ketatanegaraan.

Setidaknya konvensi ketatanegaraan harus memenuhi ciri-ciri sebagai berikut; Konvensi ketatanegaraan itu berkenaan dengan hal-hal dalam bidang ketatanegaraan; Kemudian konvensi ketatanegaraan tumbuh, berlaku, diikuti dan dihormati dalam praktik penyelenggaraan negara; serta Konvensi sebagai bagian dari konstitusi, apabila ada pelanggaraan terhadapnya tak dapat diadili oleh badan pengadilan. ${ }^{13}$

Meskipun konvensi ketatanegaraan diakui hukum yang tidak tertulis, tetapi untuk mendapatkan pemahaman yang lebih komprehensif, perlu diketahui terlebih dahulu pandangan dan kriteria kebiasaan yang dapat berubah menjadi hukum kebiasaan serta bagaimana prosesnya menjadi hukum.

Kebiasaan dalam konsep Inggris dapat dipaksakan melalui atau oleh pengadilan jika memenuhi kriteria-kriteria atau persyaratan-persyaratan tertentu.Redmond dan Bodenheimer, dua ahli hukum Inggris, mencoba merumuskan beberapa kriteria yang dimaksud. Menurut Redmond, beberapa kriteria atau persyaratan kebiasaan yang dapat diterima di pengadilan terdiri atas:

Reasonable; Not contrary to any statue or any fundamental of law; Observed as of right,i.e. nec vi clam, nec precario (not by force, not secretly, not under despute); exercise from "time immoriul",i.e. since 1189; must be definite in nature and scope; must have been exercised continuously and without interruption; must be regonized as building by those are effectif by it. ${ }^{14}$

Dari pandangan ahli di atas, Bagir Manan menyimpulkan beberapa kriteria persyaratan kebiasaan yang dapat diterima menjadi hukum oleh pengadilan, sebagai berikut: Tidak bertentangan dengan peraturan perundang-undangan yang berlaku; Tidak bertentangan dengan prinsip-prinsip common law; Telah ada untuk jangka waktu yang panjang; Telah dilaksanakan secara damai dan berkelanjutan; Dipandang oleh masyarakat sebagai kewajiban; Mempunyai arti dan ruang lingkup tertentu; Diakui sebagai sesuatu yang mengikat oleh mereka yang terkena; Layak, tidak bertentangan dengan hak dan tidak merugikan atau menimbulkan ketidakadilan bagi (kepentingan) mereka yang berada diluar kebiasaan itu. ${ }^{15}$

12 Chau Pak-kwan and Cheung Wai-lam.Process of Appointment of Senior Members of Government in Selected Countries, HK: Legislative CouncilSecretariat, 2002. Hal.1

13 Dahlan Thaib dkk, Teori dan Hukum Konstitusi, PT Grafindo Persada, Jakarta: 2006, hal.129

14 P.W.D.Redmond, General Principles of English Law, resived by.J.P.Price and I.N.Stevens, Fifth Edition,Mcdonald and Evans, Playmounth,1984, hal.17

15 Ibid.,hal.23 
Apabila syarat terciptanya kebiasaan itu diberlakukan pada kebiasaan ketatanegaraan, maka konvensi ketatanegaraan sebagai kebiasaan akan terbentuk melalui proses yang relatif lama. Karena sebagai kebiasaan, konvensi ketatanegaraan harus menerima beberapa persyaratan antara lain, (1) harus ada preseden yang timbul berkali-kali; (2) preseden yang timbul karena adanya sebab secara umum dapat dimengerti atau dapat diterima; dan (3) preseden itu karena adanya kondisi politik yang ada. ${ }^{16}$

Syarat pertama, merupakan hakikat kebiasaan itu sendiri, sebab tidak ada kebiasaan yang tidak dilakukan secara berulang-ulang. Syarat kedua, sama dengan "opinion necessitatis" atau keyakinan akan kewajiban (hukum) yang berlaku di Eropa Kontinental. Keyakinan sebagai kewajiban hukum ini idealnya tidak hanya dirasakan oleh seseorang atau golongan tertentu, tetapi oleh sebagian terbesar warga negara.Syarat ketiga, dibutuhkan karena tuntutan kondisi politik dalam skala yang luas.Karena kehidupan politik menuntut dibentuknya tindakan baru sebagai awal terciptanya konvensi ketatanegaraan atau tetap mempertahankan tradisi ketatanegaraan lama yang dianggap selama ini sudah menjadi konvensi ketatanegaraan.

Pemikiran para penulis yang diuraikan di atas cenderung bermakna sama dengan istilah konvensi ketatanegaraan sebagai kebiasaan ketatanegaraan. Jadi, menurut penulis, konvensi ketatanegaraan itu merujuk kepada kebiasaan-kebiasaan negara dalam melakukan praktik penyelenggaraan negara dan apabila ditarik dalam prespektif tatanan hukum di Indonesia, agar dapat dikatakan sebagai konvensi ketatanegaraan harus memiliki ciri; Tidak bertentangan dengan UUD NRI 1945; Tidak bertentangan dengan prinsip-prinsip bernegara; Telah ada untuk jangka waktu yang lama; Telah dilaksanakan secara terus-menerus; Dipandang sebagai sesuatu nilai yang tidak bisa di abaikan; Tidak merugikan hak konstitusional warga negara.

\section{Perkembangan Konvensi Ketatanegaraan dalam Sistem Hukum Nasional}

Melalui putusan-putusan Mahkamah Konstitusi, penulis melihat konvensi ketatanegaraan sebagai norma pendamping konstitusi yaitu guna menindaklanjuti ketikdaberdayaan peraturan tertulis dalam menyelesaikan masalah. Sebagaimana yang dikatakan oleh Ni'matul Huda mengatakan bahwa konvensi ketatanegaraan mendinamisasikan kaidah-kaidah peraturan perundang-undangan. ${ }^{17}$ Adapun bila ditelusuri lebih dalam, penggunaan konvensi sebagai ratio decidendi dalam putusan yang dibuat oleh hakim adalah adanya suatu masalah yang bersifat multitafsir dari konstitusi sehingga dibutuhkan norma hukum yang dapat memperjelas arti dari sebuah konstitusi.

Dalam sejarah sistem ketatanegaraan Indonesia konvensi mempunyai dasar karena dalam Penjelasan UUD 1945 mengakui bahwa disamping "hukum dasar tertulis" dikenal pula "hukum dasar tidak tertulis" yang oleh para ahli hukum ketatanegaraan dikenal sebagai konvensi ketatanegaraan. Menurut Kelsen, suatu norma yang validitasnya tidak dapat diperoleh dari norma lain yang lebih tinggi, kita sebut norma dasar. Semua norma yang validitasnya dapat

16 Donald A. Rumokoy, Praktik Konvensi...,op.cit., hal.60

17 Ni'Matul Huda, Hukum Tata Negara Indonesia, PT. Raja Grafindo Persada, Jakarta; 2012, hal.31 
ditelusuri kepada satu normadasar yang sama membentuk suatu sistem norma, atau suatu tata normatif. ${ }^{18}$ Norma dasar atau grundnorm tersebut diterima atau diasumsikan sebagai suatu dimana segalanya dimulai dan tidak diturunkan dari manapun. ${ }^{19}$ Dengan perkataan lain,lingkungan tata hukum sebenarnya mengikuti struktur piramida, yaitu berlakunya sesuatu kaidah yang terletak pada suatu kaidah yang lebih tinggi dan sumber puncaknya ialah Grundnorm yang hipotesis atau Ursprungsnorm yang merupakan wadah perintah Sollenkategorie. ${ }^{20}$

Hans Nawiasky mengatakan, norma tertinggi dalam sebuah negara sebaiknya tidak disebut Staatgrundnorm melainkan Staatfunda-mentalnorm, norma fundamental negara. Pertimbangannya karena Grundnorm dari suatu tatanan norma pada dasarnya tidak berubahubah, sedang norma tertinggi suatu negara mungkin berubah-ubah oleh pemberontakan. ${ }^{21}$ Dalam prespektif tata hukum nasional, Pancasila dan Pembukaan UUD 1945 disebut sebagai norma dasar (Staatfundamentalnorm). ${ }^{22}$

Rumusan hukum dasar dalam pasal-pasal yang terdapat pada batang tubuh UUD 1945 adalah pancaran dari normayang ada dalam Pembukaan UUD 1945 dan Pancasila. Di pihak lain Bagir Manan berpandangan bahwa Proklamasi adalah (Grundnorm) bagi UUD 1945, karena Proklamasi memberikan dasar yang memungkinkan pembentukan UUD NRI 1945.23

Marsillam M. Simanjuntak membedakan istilah hukum dasar dengan norma dasar. Hukum dasar merupakan refleksi dari norma dasar. Sementara itu menurut A. Hamid S. Attamimi, dengan ditetapkannya Pancasila yang termuat dalam Pembukaan UUD 1945 sebagai cita hukum dan sekaligus sebagai norma fundamental negara, maka Sistem Hukum Indonesia, baik dalam pembentukannya, dalam penerapannya, maupun penegakannya, tidak dapat dilepaskan dari nilai-nilai Pancasila sebagai cita hukum konstitutif dan regulatif, dan dari ketentuan -ketentuan Pancasila sebagi norma tertinggi yang menentukan dasar keabsahan (legitimacy) suatu norma hukum dalam Sistem Norma Hukum Republik Indonesia. ${ }^{24}$ Sedangkan menurut Jimly Assidiqie, norma atau kaidah merupakan pelembagaan nilai-nilai baik dan buruk dalam bentuk tata aturan yang berisi kebolehan, anjuran, atau perintah. Baik anjuran maupun perintah dapat berisi kaidah yang bersifat positif atau negatif sehingga mencakup norma anjuran untuk mengerjakan atau anjuran untuk tidak mengerjakan sesuatu, dan norma perintah untuk melakukan atau tidak melakukan sesuatu. ${ }^{25}$

Uraian diatas menunjukan bahwa antara kedua istilah norma dan hukum tidak terdapat perbedaan makna mendasar. Sebab norma dapat diartikan aturan, tatanan, ukuran dan lainlain; atau dipandang genus dari kaidah bermasyarakat sehingga ditemukan istilah norma sopan santun, norma kesusilaan, norma hukum, dan norma agama. Jadi norma dasardiidentikan

\footnotetext{
18 Hans Kelsen, op.cit, hal.126

19 Marsillam Simanjuntak, Pandangan Negara Integralistik, Grafiti, Jakarta, 1994, hal.26

20 Donald A Rumokoy, Praktik Konvensi Ketatanegaraan, Media Prima Aksara, Jakarta, 2011, hal.190

1 A. Hamid S. Attanami, Peranan Keputusan .....,op.cit., hal.358

22 Donal A Rumokoy, loc.cit.

23 Marsilam Simanjuntak, op.cit., hal.28

24 A. Hamid S. Attamimi, loc.cit

25 Jimly Assidiqie, Perihal Perundang-Undangan, PT. Raja Grafindo Persada, Jakarta:2011, hal.1
} 
dengan hukum dasar atau aturan dasar. Kendati demikian, tampaknya antara hukum dasar dan norma dasar digunakan dengan maksud yang berbeda.

Tidak dapat diingkari fakta bahwa umumnya ahli hukum tata negara Indonesia cenderung untuk menganggap konvensi ketatanegaraan tidak lain daripada hukum dasar tidak tertulis sebagaimana dimaksud dalam Penjelasan UUD 1945. UUD 1945 termasuk UndangUndang yang sangat singkat sehingga hukum dasar yang tidak tertulis itu timbul dan terpelihara dalam praktek penyelenggaraan negara dan harus selalu memantau kehidupan masyarakat dan negara Indonesia yang dianamis.

Sesuai dengan uraian pada Penjelasan Umum dapat ditarik kesimpulan bahwa UUD 1945 sebagai hukum dasar tertulis dan singkat itu masih dapat dilengkapi dengan aturanaturan dasar yang timbul dan terpelihara dalam praktik penyelenggaraan negara meskipun tidak tertulis. Apabila anak kalimat terakhir ini kita hubungkan dengan pendapat-pendapat A.V. Dicey, Ivor Jennings, dan Ismail Sunny, maka hal itu dalah perkataan lain untuk konvensi (ketatanegaraan). ${ }^{26}$ Pendapat serupa dikatakan oleh Bagir Manan dimana setelah mengutip Penjelasan Umum UUD 1945, ia menyatakan bahwa pengertian hukum dasar yang tidak tertulis itu cenderung kepada pengertian konvensi, bukan hukum adat sebagaimana yang dikenal dalam masyarakat Indonesia maupun pelajaran hukum di Indonesia.Kecenderungan pengertian ini didasarkan pada anak kalimat yang berbunyi aturan-aturan dasar yang timbul dan terpelihara dalam praktik penyelenggaraan negara."Sedangkan hukum adat bukan hukum yang terutama timbul dan terpelihara dalam praktik pnyelenggaraan negara.Hukum adat terbentuk melalui putusan-putusan penguasa adat. ${ }^{27}$

Uraian di atas mencoba menemukan makna dari rumusan "aturan-aturan dasar yang terpelihara dalam praktik penyelenggaraan negara" pada Penjelasan Umum UUD 1945. Ada dua kemungkinan maksud yang terkandung dalam rumusan itu, pertama sebagai kebiasaan di lapangan Hukum (tata negara) Adat, dan kedua merujuk kepada konvensi ketatanegaraan. Dari kedua kemungkinan itu Bagir Manan menyimpulkan bahwa hal itu lebih tepat bila diartikan sebagai konvensi ketatanegaraan. ${ }^{28}$ Ketiga, pendapat Ismail Suny mengakui di Indonesia konvensi ketatanegaraan dikenal dalam praktik bernegara berdasarkan Penjelasan Umum UUD 1945. ${ }^{29}$ Ketiga ahli hukum tata negara itu sependapat bahwa hukum dasar tidak tertulis yang dirumuskan dalam Penjelasan Umum UUD 1945 tidak lain dari pada landasan hukum sekaligus penjelasan makna daripada konvensi ketatanegaraan Indonesia.

\section{Konvensi Ketatanegaraan Dibawah UUD Negara Republik Indonesia Tahun 1945}

Amandemen UUD NRI 1945 yang terakhir menghapuskannya Penjelasan UUD 1945 sehingga tanpa Penjelasan lagi, kemudian yang menjadi pertanyaan bagaimanakah eksistensi

26 Ibid

27 Ibid hal. 18

28 Ibid

29 Ismail Suny, Pergeseran Kekuasaan Eksekutif, dalam buku Donald A. Rumokoy, Praktik Konvensi Ketatanegaraan, Media Prima Aksara, Jakarta,2011. Hal.194 
konvensi ketatanegaraan setelah tanpa pejelasan dalam Undang-undang Negara Republik Indonesia? Apakah masih diakui?Apabila dikembalikan kepada pengertian dari konvensi sebagai hukum yang tidak tertulis dan mengutip yang dikatakan Sudikno Mertokusumo dalam buku nya yang mengatakan bahwa tidak mungkin peraturan perundang-undangan mengatur seluruh kehidupan bernegara maka nilai-nilai yang berada diluar dari peraturan perundangundangan harus diperhatikan. ${ }^{30}$ Maka oleh karena itu relevansinya konvensi ketatanegaraan menurut penulis tetap diakui dengan dasar keberlakuan konvensi ketatanegaraan pasca dihapusnya penjelasan UUD 1945 menggunakan Pasal 2 aturan peralihan.

Berkenaan dengan pengertian konvensi ketatanegaraan menurut sistem di Indonesia, Bagir Manan menjelaskan Konvensi atau (hukum) kebiasaan ketatanegaraan adalah (hukum) yang tumbuh dalam praktik penyelenggaraan negara, melengkapi, menyempurnakan, menghidupkan (mendinamisasi), kaidah-kaidah hukum perundang-undangan atau hukum adat ketatanegaraan. ${ }^{31}$ Sehingga, menurut penulis sepakat dengan apa yang dikatakan oleh Donald A. Rumokoy bahwa konvensi ketatanegaraan adalah segenap kebiasaan atau tindakan ketatanegaraan yang bersifat mendasar, yang dilakukan dalam menyelenggarakan aktivitas bernegara oleh alat-alat kelengkapan negara, dan belum diatur dalam konstitusi serta peraturan ketatanegaraan lainnya, dengan maksud untuk melengkapi ketentuan-ketentuan ketatanegaraan atau sebagai faktor pendinamisasi pelaksanaan konstitusi.

\section{Landasan Yang Digunakan Mahkamah Konstitusi dalam Pengujian Undang-undang dalam Sistem Hukum Nasional}

Kekuasaan Mahkamah Konstitusi untuk menguji undang-undang yang bertentangan dengan UUD NRI 1945 merupakan cerminan diterapkannya mekanisme check and balances di Indonesia di mana kekuasaan pembuat undang-undang selama ini berada pada badan legislatif tidak dapat diuji oleh lembaga yudisial. Dengan berwenangnnya Mahkamah Konstitusi menguji undang-undang, maka semua pengadilan dan lembaga negara dan lembaga-lembaga lainnya termasuk pemerintah daerah harus terikat dengan putusan mahkamah konstitusi.

Undang-undang merupakan produk demokrasi atau produk kehendak orang banyak. Jika undang-undang telah dibahas dan disetujui bersama oleh DPR dan Presiden, lalu kemudian disahkan oleh Presiden maka berarti undang-undang yang bersangkutan telah mencerminkan kehendak politik mayoritas suara rakyat. Namun, suara mayoritas rakyat tidak selalu identik dengan suara keadilan dan kebenaran konstitusi. Kebenaran mayoritas dapat saja berubah menjadi tirani mayoritas, oleh karenanya dibutuhkan check and balances yang menjaga objektifitas dari suara mayoritas tersebut. Oleh sebab itu, jika undang-undang bertentangan dengan undangundang dasar, maka udang-undang itu baik sebagian materinya atau seluruh dapat dinyatakan tidak mengikat untuk umum, meskipun yang menyatakannya hanya terdiri atas 5 dari 9 orang hakim pada mahkamah konstitusi. Dengan cara demikian, melalui proses peradilan tata usaha

30 Sudikno Mertokusumo, Penemuan Hukum, Liberty, Yogyakarta: 2007, hal. 106

31 Bagir Manan, Konvensi...,op.cit., hal.15 
negara yang fair, independent, imparsial, dan terbuka, mahkamah konstitusi dapat menjalankan fungsinya sebagai pengimbang atau penyeimbang. Melalui peradilan konstitusi ini ditegaskan pula bahwa undang-undang dasar the supreme law, dapat benar-benar ditegakkan dalam praktik penyelenggaraan negara. ${ }^{32}$

Pihak yang berhak mengajukan permohonan pengujian undang-undang adalah: (i) perorangan atau kelompok warga negara; (ii) kesatuan masyarakat hukum adat yang masih hidup, sesuai dengan perkembangan dan prinsip negara kesatuan Republik Indonesia, yang diatur dalam undang-undang; (iii) badan hukum privat atau badan hukum publik; atau (iv) lembaga negara. ${ }^{33}$ Berdasarkan Jurisprudensi Mahkamah Konstitusi, kerugian konstitusional yang timbul karena berlakunya suatu undang-undang harus memenuhi 5 (lima) syarat, yaitu: (i) adanya hak konstitusional Pemohon yang diberikan oleh UUD NRI 1945; (ii) bahwa hak konstitusional tersebut dianggap oleh Pemohon telah dirugikan oleh suatu undang-undang yang diuji; (iii) bahwa kerugian konstitusional Pemohon yang dimaksud bersifat spesifik (khusus) dan actual atau setidak-tidaknya bersifat potensial yang menurut penalaran yang wajar dapat dipastikan akan terjadi; (iv) adanya hubungan sebab akibat (causal verband) antara kerugian dan berlakunya undang-undang yang dimohonkan untuk diuji; dan (v) adanya kemungkinan bahwa akan dikabulkannya permohonan maka kerugian konstitusional yang didalilkan tidak akan atau tidak akan terjadi

Mahkamah Konstitusi juga dapat menguji undang-undang yang bersifat multitafsir yang sehingga dapat merugikan hak konstitusional secara individu atau kelompok. Namun yang menjadi pertanyaannya adalah apakah sumber hukum yang yang tertulis saja dapat digunakan mahkamah konstitusi dalam melakukan penafsirannya? Inilah yang menarik dalam pokok tulisan yang ingin dianalisi oleh penulis adalah penggunaan konvensi ketatanegaraan sebagai sumber hukum bagi mahkamah konstitusi dalam melakukan pengujian undang-undang.

Dalam melakukan pemecahan sebuah masalah atau kasus seorang akan melakukan sebuah interpretation (penafsiran) yang akan mendukungnya untuk mengeluarkan putusan. Interpretasi (interpretation, interpracion), adalah sebuah nomina serapan yang diadopsi dari sebutan latin: 'interpretatio dalam perkataan Yunani ia diungkapkan sebagai 'herenuetuk' sebuah istilah yang berasal dari kata kerja 'hereneuein' yang berarti menginterpretasi, kata bendanya sendiri adalah 'hereneuia' yang berarti penafsiran atau interpretasi. ${ }^{34}$ Secara umum, 'hermenueti' alias interpretasi dipandang sebagai: "The act or result of interpreting, explanation, meaning, translation exposition ${ }^{35}$. Dari pengertian diatas tentunya dapat diartikan sebagai proses dan sebagai hasil dari proses itu.

32 Jimly Asshidiqie, Pengantar Ilmu Hukum Tata Negara, Sekretariat Jendral dan Kepaniteraan Mahkamah Konstitusi Republik Indonesia, Jakarta: 2006, hal. 336

33 Terhadap legal standing Pemohon beserta syrat permohonannya, lihat dalam Pasal 51 UU No. 24 Tahun 2003 tentang Mahkamah Konstitusi dan Pasal 3 s/d Pasal 5 Peraturan Mahkamah Konstitusi Nomor 06/PMK/2005 tentang Pedoman Beracara dalam Perkara Pengujian Undang-undang.

34 Hans Kelsen, The Pure Theory of law, translation: Max Knight (London \& Los Angeles: University of California Press, 1998), hal. 47

35 M.Agnes, Webster's New word college dictionary, ed.4 (New Delhi: IDG Books India Ltd). hal. 747 
Menginterpretasi aturan hukum berarti kegiatan sebagai usaha menerapkan isi aturan hukum, atau persisnya menetapkan apa yang bisa dijelaskan dari kaidah hukum yang tercantum dalam aturan hukum, serta menentukan seberapa lingkup (wilayah) penetapanya (aturan hukum itu). Dengan demikian, ini adalah kesibukan yang boleh dibilang terpusat pada usaha "mendistilasi kaidah" Yakni : kaidah yang tercantum dalam aturan hukum, untuk pada gilirannya dijelaskan seberapa luas lingkup penerapan darinya (aturan hukum terkait). ${ }^{36}$ Dalam sejarah interpretasi terhadap teks-teks peraturan perundang-undangan hadir sebagai reaksi atas situasisituasi problematikal berkenaan dengan: Pernyataan-pernyataan hukum (rechtsvrangen). Konflik-konflik dibidang hukum.

Diarahkan semuanya itu kepada pemberian jawaban terhadap pertanyaan-pertanyaan tentang hukum dan hal-hal berkenaan dengan penyelesaian-penyelesaian terhadap sengketasengketa yang konkret.Didalamnya diajukan (dipersoalkan) pertanyaan-pertanyaan yang berkenaan dengan penafsiran (penjelasan) dan penerapan aturan-aturan hukum.Serta pertanyaanpertanyaan yang berhubungan dengan makna dari fakta-fakta yang terhadap hukumnya harus diterapkan.Kegiatan menginterpretasi dilakukan untuk menemukan penyelesaian-penyelesaian dan jawaban-jawaban berdasarkan kaidah hukum, yang lebih kurang cermat mengemukakan bagaimana terhadap situasi-situasi problematika tertentu seyogyanya harus diberikan reaksi.

Dalam perkembanganya kegiatan melakukan intepretasi aturan hukum tidak sekedar memberi penafsiran atau penjelasan atas teks-teks hukum yang tidak jelas dan tidak lengkap itusaja, tapi juga sebagai rechtsvinding (penemuan hukum). Karenanya kegiatan menginterpretasi teks-teks hukum, telah dilihat sebagai sebuah otoritas hukum (hukum yang ada diatasnya), yang didalamnya seorang subjek interpretator sekaligus hendak mewujudkan inti dari keseluruhan rute-rute pengembanan hukum, baik pada derajat yang ilmiah maupun yang praktikal atau pembentukan dan penerapan hukum ${ }^{37}$.

Interpretasi selalu beranjak dari sebuah "prapemahaman" dan "prapengertian". Seorang interpretator bertugas menjernihkan hal-hal yang dianggap kabur atau kurang jelas dari sebuah peraturan perundang-undangan yakni dengan menyelidiki retail setiap fase-fase dalam proses menginterpretasi. Kedalamnya ia harus memformulasi sebuah "metode" yang akan digunakan untuk mengukur seberapa jauh kemungkinan masuknya pengaruh-pengaruh hal-hal subjektif dalam dirinya terhadap usahanya menyajikan objektivitas yang diharapkan. Interpretasi adalah kegiatan yang bersifat "treadik", alias mempunyai tiga segi kegiatan yang saling berkaitan. Dalam hal ini terdapat pertentangan antara pikiran yang disorotkan pada objek dan pikiran penafsir sendiri. Tidak hanya itu dalam merumuskan suatu hipotesa tentang aturan hukum itu, ia dituntut bertindak sebagaimana ilmuwan umumnya. A scientific attitude was linked with an ardent curiosity fertile imajianation and love of experimen inqury. ${ }^{38}$ Sebuah sikap ilmiah berkaitan dengan keingin-tahuan yang berapi-api, daya khayal dan kecintaan yang berlebihan

\footnotetext{
36 Herman Bakir, Kastil Teori Hukum, PT Indeks, Jakarta, 2005, hal.49

37 Ibid, hal.53

38 Ibid, hal.54
} 
pada eksperimen.Kembali kepada pembahasan mengenai kegiatan interpretasi aturan hukum ini, Scholten mengatakan bahwa interpretasi adalah suatu usaha merangkum aturanaturan tidak tertulis untuk ditempatkan dalam formula tertentu. Interpretator dituntut untuk menjelaskan aturan-aturan yang ditetapkan oleh otoritas, menentukan jangkauannya (makna) yang terkandung didalamnya dengan menelusuri sejarah dan tujuannya, dengan menenmpatkan aturan itu dalam sistem yang melingkupinya, dengan menganalisis kata-kata yang digukanakan atau dengan cara lain menguraikan aturan-aturan itu sedemikian rupa sehingga ia siap untuk diterapkan pada kejadian-kejadian yang dihadapi atau yang dibayangkan dapat muncul. ${ }^{39}$

Bagi Scholten, hal menginterpretasi selalu terjadi berdasarkan pikiran-pikiran tertentu, yakni : Latar belakang dari hukum; Bentuk-bentuk logikalnya; Kadar muatan keadilannya; dan satu-satunya tujuan dari menginterpretasi aturan hukum adalah penerapan dan transformasi aturan-aturan hukum itu sendiri kedalam dunia realitas atau kehidupan nyata.

Interpretasi mengisi kerangka aturan-aturan otoritatif berdasarkan undang-undang ataupun putusan-putusan baru yang dipandangnya tersembunyi dala ruang lama. Interpretasi sekaligus mengkonstruksi hukum tersebut, kedalam sebuah bangunan yang baru pula. Interpretasi menempatkan abstraksi hubungan kemasyarakatan tertentu dibawah pengaruhpengaruh hukum, aturan tersebut tertata secara hirarki, bahwa yang lebih kongkret mengacu pada tingkatan yang lebih umum daya jangkauannya, dengan demikian membangun suatu sistem yang konseptual. Bahwa dalam tiap hukum terdapat sistem, dan sistem itu harus diwedarkan dalam sebuah karya ilmiah dan sekaligus karya tersebut dihaluskan dan diejawantahkan (diolah lebih jauh) oleh ilmuwannya. ${ }^{40}$

Pada saat kita melakukan legal reasoning sesungguhnya kita tengah mengupayakan suatu proses berpikir yuridik yang disebutkan Arief Sidharta sebagai proses berpikir "problematik tersistematisasi" oleh karenanya dikatakan sebagai kombinasi dari dua model berpikir, yakni model berpikir sistemik (aksiomatik) bertolak dari "kebenaran bebas-ragu" kebenaran bebasragu adalah model kebenaran yang tidak bisa diragukan. Semisal bahwa "setiap hari matahari akan terbit, dan setiap hari matahari akan tenggelam, dan pada waktu lain matahari tidak ada (ada pada bagian bumi lain) dan berfikir problematik yakni berpikir yang bertolak dari kebenaran yang tidak bebas-ragu, yang berupaya mencapai kesimpulan yang paling aksep tabel atau "plausibel" (masuk akal).

\section{Analisis Penggunaan Konvensi Ketatanegaraan dalam Praktik Pengujian Undang- Undang oleh Mahkamah Konstitusi di Indonesia}

Konvensi ketatanegaraan dijadikan sebagai sumber hukum dalam pengujian undangundang, pada putusan No.49/PUU-VIII/2010 dapat dilihat penggunaan konvensi ketatanegaraan sebagai norma hukum yang tidak tertulis digunakan mahkamah konstitusi dalam melakukan penafsiran konstitusional. Dalam melakukan penafsiran konstitusi, para hakim konstitusi bebas

\footnotetext{
39 Herman Bakir, Kastil Teori Hukum, PT Indeks, Jakarta, 2005, hal. 57

40 Ibid
} 
memilih metode intepretasi yang digunakan mereka dalam melakukan pengujian undangundang. Makna ketentuan dalam suatu peraturan perundang-undangan dapat juga ditafsirkan dengan cara meneliti sejarah pembentukan peraturan itu sendiri. Penafsiran ini dikenal dengan interpretasi historis. Terdapat dua macam interpretasi historis, yaitu: Penafsiran menurut sejarah undang-undang, dan Penafsiran menurut sejarah hukum.

Penafsiran menurut sejarah undang-undang hendak mencari maksud ketentuan undangundang seperti dikehendaki oleh pembentuk undang-undang. Pikiran yang mendasari metode interpretasi ini ialah bahwa undang-undang adalah kehendak pembentuk undang-undang yang tercantum dalam teks undang-undang. Interpretasi menurut sejarah undang-undang ini disebut juga interpretasi subjektif, karena penafsir menempatkan diri pada pandangan subjektif pembentuk undang-undang, sebagai lawan interpretasi menurut bahasa yang disebut metode objektif. ${ }^{41}$ Melalui sejarah hukum, hakim dapat menilai akan hal ini melalui praktik-praktik ketatanegaraan yang dilakukan berulang-ulang tanpa bertentangan dengan konstitusi tertinggi yaitu UUD NRI 1945.

Sebagaimana pendapat Jimly Asshiqddiqie, konvensi ketatanegaraan termasuk nilainilai konstitusi yang tetap dipatuhi, sebagai norma penyeleras dari UUD NRI 1945. ${ }^{42}$ Oleh karena itu konvensi ketatanegaraan mempunyai kedudukan yang sangat penting, dan diterima dan dijalakan seperti halnya undang-undang. Kemudian bila dikaitkan pula dengan 4 (empat) alat ukur untuk menguji konsitusionalitas suatu undang-undang, antara lain: (i) naskah undangundang dasar yang resmi tertulis beserta; (ii) dokumen-dokumen tertulis yang terkait erat dengan naskah undang-undang dasar itu, seperti risalah-risalah, keputusan dan ketetapan MPR, undangundang tertentu peraturan tata tertib, dan lain-lain; serta (iii) nilai-nilai konstitusi yang hidup dalam praktek ketatanegaraan yang telah dianggap sebagai bagian yang tidak dapat terpisahkan dari keharusan dan kebiasaan dalam penyelenggaraan kegiatan bernegara; dan nilai-nilai yang hidup dalam kesadaran kognitif rakyat serta kenyataan perilaku politik dan hukum warga negara yang dianggap sebagai kebiasaan dan keharusan-keharusan yang ideal dalam peri-kehidupan berbangsa dan bernegara. ${ }^{43}$ Konvensi ketatanegaraan yang merupakan non-legal rules yang mengatur cara bagaimana legal rules diterapkan dalam praktik. Hubungan antara hukum dan konvensi ketatanegaraan sangat penting dan mempunyai karakteristik yang fundamental dan struktur ketatanegaraan.Bahkan, dalam penyelenggaragaan negara konstitusional. Dapat dikatakan, tidak semua untuk menyelesaikan berbagai perselisihan dan sengketa konstitusional dalam praktek ketatanegaraan dengan hanya mengandalkan norma hukum yang tertulis saja.

\section{Konvensi Sebagai Pendamping Konstitusi}

Dicey mengatakan bahwa konvensi ketatanegaraan yang berlaku dan dihormati dalam kehidupan ketatanegaraan, walaupun pelanggaraannya tidak dapat diadili oleh badan

41 Mahkamah Konstitusi, Hukum Acara Mahkamah Konstitusi...,Op.cit, hal.73

42 Jimly Asshidiqie, Pengantar Ilmu Hukum...,Op.cit, hal. 256

43 Jimly Assidiqie, Hukum Acara Pengujian Undang-Undang, Konstitusi Press, Jakarta:2006, hal.8 
pengadilan. ${ }^{44}$ Mengapa demikian? Berdasar dari putusan-putusan, penulis melihat bahwa segala aturan yang didapatkan berdasarkan konvensi tidak bisa dikenakan sanksi, karena norma konvensi ketatanegaraan sama halnya dengan konstitusi yang tidak dapat dikenakan sanksi berupa kurungan atau pun lainnya, dikarenakan semuanya ini merupakan landasan untuk bergeraknya para pemegang jabatan politik untuk menjalakan fungsi dan jabatan sesuai yang dipercayakan kepadanya, dan sudah jelas sanksinya merupakan sanksi politik saja. Lalu yang jadi pertanyaan kemudian, apakah konstitusi sama dengan konvensi ketatanegaraan? Untuk menjawab itu, perlu untuk diketahui apa pengertian dari konstitusi. Konstitusi merupakan segala ketentuan atau aturan tentang ketatanegaraan. ${ }^{45}$ Dalam hal ini penulis akan kaitkan dengan konstitusi yang dianut Republik Indonesia berdasarkan asas legalitas yaitu konstitusi tertulis, dimana segala ketentuan dan aturan dasar dituang didalam sebuah naskah tertulis yang merupakan kesepakatan dan landasan bagi setiap penyelenggara negara dalam bertindak menjalankan kewenangannya.

Sedangkan konvensi ketatanegaraan, merupakan kebiasaan atau praktik-praktik ketatanegaraan yang merupakan norma yang tidak tertulis namun dihormati dan dipatuhi ${ }^{46}$ Dari analisis yang dilakukan oleh penulis, penulis melihat konvensi ketatanegaraan yang mendeskripsikan dan menjelaskan bagaimana konstitusi dijalankan, tumbuh dan berkembang. Fungsi utamanya mengadaptasi struktur kepada fungsinya, karena sifat kompleksitas dari aturan dari konstitusi maka dibutuhkan norma sebagai pendamping untuk menjalankan dari sebuah tujuan atau bahkan citadari ketatanegaraan di Indonesia.

O. Hood Phillips and Paul Jackson konvensi ketatanegaraan sebagai: rules of political practice which regarded as binding by those wo whom they apply, which are not laws as they are not enforced by courts or the house of parliament. Atau dengan kata lain yang disimpulkan oleh penulis, konvensi ketatanegaraan merupakan aturan dari praktik politik yang merupakan perpanjangan-tanganan dari pelaksanaan konstitusi itu sendiri.

Berpegang kepada pendapat penulis pada bab sebelumnya, sebagaimana konvensi ketatanegaraan yang telah penulis katakan merupakan sebagai norma pendamping dari konstitusi yang berfungsi mendinamisasikan kaidah-kaidah peraturan perundang-undangan, bisa di ambil kebenarannya dari putusan-putusan yang ada dimana konvensi ketatanegaraan dapat menjadi sumber hukum, pedoman bagi para hakim untuk menyelesaikan masalah ketatanegaraan dan bahkan menurut penulis mampu menggeserkan peraturan perundang-undangan yang perlu di intepretasikan sehingga menjadi hukum itu sendiri. Disinilah letak bagaimana konvensi ketatanegaraan berfungsi sebagai mendinamisasikan agar kaidah-kaidah peraturan perundangundangan tetap dapat berjalan selaras dengan konstitusi tertinggi yaitu UUD Negara Republik Indonesia Tahun 1945 tanpa merugikan hak konstitusional warga negara.

Konvensi sebagai alat intepretasi, digunakan Mahkamah Konstitusi dalam melakukan

\footnotetext{
44 H. Dahlan Thain, dkk, Teori dan Hukum Konstitusi, PT Raja Grafindo Persada, Jakarta : 2012, hal.130

45 _www.KamusBesarBahasalndonesia.org / diakses tanggal 16 Desember 2012

46 H. Dahlan Thain, dkk, Teori dan Hukum Konstitusi...,Op.Cit, hal.129
} 
penafsiran ketika peraturan perundang-undangan yang tertulis tidak dapat mengatur segala aspe kehidupan masyarakat.Sebagai alat intepretasi ini konvensi ketatanegaraan dapat membantu Mahkamah Konstitusi untuk menyelesaikan permasalah secara cepat dan jelas agar tidak ada dari warga negara yang dirugikan hak konstitusionalnya.Sebagaimana tujuan akhir dari konvensi ketatanegaraan menurut penulis, untuk mengamankan supremasi hukum dari kekuasaan politik, yang harus dilaksanakan sedemikian rupa untuk melaksanakan pemerintahan yang demokratik.

\section{Konvensi Sebagai Batu Uji}

Undang-Undang Dasar dan Konvensi Konstitusi berkaitan erat.Konvensi konstitusi mengandaikan adanya kerangka hukum, dan tidak ada dalam kekosongan hukum.Perbedaan antara undang-undang dan konvensi konstitusi adalah bahwa undang-undang berlaku oleh pengadilan, tetapi konvensi konstitusi tidak ditegakkan oleh pengadilan.Jika ada konflik antara konvensi konstitusi dan hukum tertulis pengadilan harus menegakkan hukum tertulis.Konvensi konstitusi dapat digunakan untuk mengisi celah-celah dalam struktur hukum penyelenggaraan ketatanegaraan. Dalam kasus konstitusi tertulis, Konvensi konstitusi sangat penting untuk memberikan aturan untuk penyelenggara negara tentang kebiasaan-kebiasaan yang telah tumbuh, berkembang, dan telah dianggap sebagai sesuatu yang tidak boleh diabaikan. Mahkamah Konstitusi menggunakan konvensi sebagai salah satu batu uji dalam melakukan pengujian undang-undang, dalam pengujian Pasal 10 Undang-undang Nomor 39 Tahun 2008 tentang Kementerian Negara yang berbunyi demikian “ Dalam hal terdapat beban kerja yang membutuhkan penanganan secara khusus, Presiden dapat mengangkat Wakil menteri pada Kementerian tertentu, yang dianggap pasal tersebut bertentangan dengan Pasal 17 UUD NRI 1945 yang menyatakan “(1) Presiden dibantu oleh menteri-menteri negara, (2) Menteri-menteri itu diangkat dan diberhentikan oleh Presiden, (3) Setiap menteri membidangi urusan tertentu dalam pemerintahan, (4) Pembentukan, pengubahan, dan pembubaran kementerian negara diatur dalam undang-undang", karena dalam Pasal 17 UUD 1945 tidak ada menyebutkan jabatan Wakil Menteri.

Dalam hal ini peran konvensi terlihat jelas bukan hanya sebagai sumber hukum, namun juga sebagai hukum dasar yang dapat dijadikan Mahkamah Konstitusi untuk menjadi dasar hukum dalam putusannya. Karena berdasarkan praktik ketatanegaraan bukan pertama munculnya Wakil Menteri, dan yang sangat mendasar adalah bagaimana sebenarnya hak preogatif yang melekat pada jabatan, yang selama ini diterima dan telah menjadi konvensi ketatanegaraan atau kebiasaan ketatanegaraan di Indonesia yang juga sebagai hukum dasar bagi Presiden didalam menjalankan tugasnya.

\section{Kesimpulan}

Putusan Mahkamah Konstitusi Nomor 46/PUU-VIII/2010 tentang Pengujian UndangUndang Nomor 1 Tahun 1974 tentang Perkawinan terhadap Undang-Undang Dasar Negara 
Republik Indonesia Tahun 1945, yang menyatakan bahwa pasal 43 ayat (1) Undang-Undang Nomor 1 Tahun 1974 bertentangan dengan Undang-Undang Dasar Negara Republik Indonesia secara bersyarat (conditionally unconstitusional) berdampak positif untuk perlindungan anak. Putusan tersebut menegaskan kembali ayah biologis/kandung merupakan pihak yang bertanggung jawab terhadap perlindungan anak sebagaimana terdapat dalam ketentuan undangundang perlindungan anak.Hal ini terlepas dari sah atau tidak sah perkawinan yang dilakukan oleh ayah biologis/kandung dengan ibu biologis/kandung.

Terdapat 3 (tiga) materi yang perlu dilakukan upaya sinkronisasi yaitu; Tanggung jawab ayah biologis/kandung dengan anak yang diluar perkawinan yang sah; Pembuktian adanya hubungan darah antara ayah biologis/kandung dengan anak yang lahir di luar perkawinan yang sah; Akta yang menerangkan bahwa terdapat hubungan darah antara ayah biologis/kandung dengan anak yang lahir di luar perkawinan yang sah.

Undang-undang perkawinan perlu direvisi untuk menindaklanjuti putusan Mahkamah Konstitusi yakni bahwa untuk anak di luar perkawinan yang sah tetap mempunyai hubungan dengan ayah biologis/kandung sebatas tanggung jawab untuk mengasuh, memelihara, mendidik dan melindungi anaknya tersebut berdasarkan hubungan darah.Pasca adanya putusan Mahkamah Konstitusi Nomor 46/PUU-VIII/2010 harus dilakukan revisi terhadap undangundang perkawinan, undang-undang perlindungan anak dan undang-undang administrasi kependudukan.Hal ini dilakukan untuk mengharmonisasi 3 (tiga) undang-undang agar materinya tidak saling bertentangan dan juga untuk menindaklanjuti putusan Mahkamah Konstitusi tersebut.

\section{Daftar Bacaan}

\section{Buku}

Algra, N.E, Gokkel, H.R.W, dkk, Kamus Istilah Hukum Fockema Andreae Belanda Indonesia, diterjemahkan oleh Saleh Adiwinata dkk (Binacipta 1983)

Apeldoorn, L.J.van, Pengantar Ilmu Hukum, diterjemahkan oleh Oetarid Sadino (Pradnya Paramita 2008)

Darmodiharjo, Darji, Shidarta, Pokok-pokok Filsafat Hukum, Apa Dan Bagaimana Filsafat Hukum Indonesia (ed revisi, PT.Gramedia Pustaka Utama 2006)

Dworkin, Ronald, Taking Rights Seriously (Harvard University Press 1977, 1978) Sovereign Virtue, The Theory And Practice Of Equality (Harvard University Press 2000) 
Hernoko, Agus Yudha, Asas Proporsionalitas Dalam Kontrak Komersial (Kencana Prenada Media Group 2010)

Huijbers, Theo, Filsafat Hukum Dalam Lintasan Sejarah (cet.viii, Kanisius 1995)

Hutchinson, Terry, Researching And Writing In Law (Third Edition, Thomson Reuters Professional 2010)

Joni, Muhammad; Tanamas, Zulchaina Z, Aspek Hukum Perlindungan Anak Dalam Perspektif Konvensi Hak Anak (PT. Citra Aditya Bakti 1999)

Juni, Efran Helmi, Filsafat Hukum (Pustaka Setia 2012)

Muhammad, Abdulkadir, Hukum Perdata Indonesia (PT.Citra Aditya Bakti 2000)

Marzuki, Peter Mahmud, Penelitian Hukum (cet ke-6, Kencana Prenada Media Group 2010)

--------, Pengantar Ilmu Hukum (cet ke-3, Kencana Prenada Media Group 2009) MKRI, KRHN, Cetak Biru Membangun Mahkamah Konstitusi Sebagai Institusi Peradilan Konstitusi Yang Modern Dan Terpercaya (Yayasan Tifa 2004)

Prasetyo, Dossy Iskandar, Tanya, Bernard L, Hukum Etika \& Kekuasaan (Genta Publishing 2011)

Prawirohamidjojo, R.Soetojo, Pluralisme Dalam Perundang-undangan Perkawinan Di Indonesia (Airlangga University Press 1988)

--------, Pohan, Marthalena, Hukum Orang Dan Keluarga (Airlangga University Press 1991)

Prinst, Darwan, Hukum Anak Indonesia (PT. Citra Aditya Bakti 2003)

Rawls, John, A Theory Of Justice (Revised Edition, The Belknap Press Of Harvard University Press, 1971, 1999)

Rofiq, Ahmad, Hukum Islam Di Indonesia (PT RajaGrafindo Persada 2003)

Subekti, Pokok-Pokok Hukum Perdata (cet ke-33, Intermasa 2008) 
Thomson Reuters, Bryan A Garner, Black's Law Dictionary (9th ed Westlaw International 2009)

Eddyono, Supriyadi W, Pengantar Konvensi Hak Anak, Seri Bahan Bacaan Kursus HAM Untuk Pengacara X (Lembaga Studi Dan Advokasi Masyarakat (ELSAM) 2005)

Habiburrahman, 'Posisi Dan Kedudukan Anak Di Luar Pernikahan' (2012) Rakernas Mahkamah Agung

Parness, Jeffrey A. and Townsend, Zachary, 'Legal Paternity (And Other Parenthood) After Lehr AndMichael H' (2012) University of Toledo Law Review

Forder, Caroline dan Saarloos, Kees, 'The Establishment of Parenthood, a Story of Successful Convergence?' (2007) Faculty of Law, Universiteit Maastricht Working Papers

\section{Peraturan Perundang-undangan Dan Peraturan Lainnya}

Undang-Undang Dasar Negara Republik Indonesia Tahun 1945.

Undang-Undang Nomor 1 Tahun 1974 tentang Perkawinan (Lembaran Negara Republik Indonesia Tahun 1974 Nomor 1, Tambahan Lembaran Negara Republik Indonesia Nomor 3019).

Kitab Undang-Undang Hukum Perdata (Burgelijk Wetboek), Staatsblad Nomor 23 Tahun 1847

Undang-undang Nomor 39 Tahun 1999 tentang Hak Asasi Manusia (Lembaran Negara Republik Indonesia Nomor 165 Tahun 1999 dan Tambahan Lembaran Negara Republik Indonesia Nomor 3886).

Undang-undang Nomor 23 Tahun 2002 tentang Perlindungan Anak (Lembaran Negara Republik Indonesia Tahun 2002 Nomor 109, Tambahan Lembaran Negara Republik Indonesia Nomor 4235).

Undang-Undang Nomor 23 Tahun 2006 tentang Administrasi Kependudukan (Lembaran Negara Republik Indonesia Tahun 2006 Nomor 124, Tambahan Lembaran Negara Republik Indonesia Nomor 4674). 
Undang-Undang Nomor 48 Tahun 2009 tentang Kekuasaan Kehakiman (Lembaran Negara Republik Indonesia Nomor 157 Tahun 2009 dan Tambahan Lembaran Negara Republik Indonesia Nomor 5076) 